\title{
異なる作用温度，照度レベル，光源の組み合わせが人体の 生理・心理反応に及ぼす複合的影響 \\ THE COMBINED EFFECT OF OPERATIVE TEMPERATURE, ILLUMINANCE AND LIGHT SOURCE ON THE HUMAN PHYSIOLOGICAL AND PSYCHOLOGICAL RESPONSES
}

\author{
石井 仁*，堀越哲美** \\ Jin ISHII and Tetsumi HORIKOSHI
}

\begin{abstract}
The objective of this study is to clarify the combined effects of operative temperature, illuminance and light source on the human physiological and psychological responses. The following results were obtained: 1) Skin temperature was affected with air temperature and was not affected with illuminance and light source. 2) When operative temperature was $25^{\circ} \mathrm{C}$ or $28^{\circ} \mathrm{C}$ and light source was incandescent lamp, thermal sensation was affected with air temperature and illuminance. 3) When operative temperature was $25^{\circ} \mathrm{C}$ or $28^{\circ} \mathrm{C}$, thermal sensation was affected with air temperature and light source. 4) When operative temperature was $25^{\circ} \mathrm{C}$ or $28^{\circ} \mathrm{C}$, comfortable sensation was affected with air temperature and illuminance. 5) When operative temperature was $25^{\circ} \mathrm{C}$ or $28^{\circ} \mathrm{C}$ and illuminance was $10001 \mathrm{x}$, comfortable sensation was affected with air temperature and light source
\end{abstract}

keywords : operative temperature, illuminance, light source, skin temperature, thermal sensation, comfortable sensation

作用温度, 照度, 光源, 皮䖉温, 温冷感, 快適感

1.はじめに

一般に、人は光源の色温度が高いと光色は青みがかった白に見え涼 しく感し、反対に低いと赤みがかった白に見え暖かく感じる1)とされ ている。Kruithof ${ }^{2)}$ は、心地上く感じる光源の色温度と照度レベルと の関係の研究を行っている。それによると低照度で色温度が低い場 合、人は暗く感じ、低照度で色温度が高い場合には寒く感じる。一方、 高照度で色温度が低い場合、人は不快に感じると報告されている。中 野ら ${ }^{3)}$ は日本人男女を被験者に用い、一定照度条件下で気温と色温度 の組み合わせが人体生理心理反応に及ぼす研究を行い、Kruithof と同 様の結果を得た。またCIE屋内照明ガイド4による光色の好みも Kruithof とほほ同様である。しかし乾 ${ }^{5)}$ は、CEによる光色の好みは 主として北西ヨーロッパ諸国が中心となってつくられたもので、気候 の異なる国で適用するときは修正が必要であると指摘している。この ように、Kruithof の結果や CEEのガイドを日本人に適用させる場合、 人種、風土等の差違を考慮した検討をする必要性があると考えられ る。まて、人は暖色系の色相を暖かく感し、寒色系の色相を涼しく感 ビるという hue he at 仮説 ${ }^{6)}$ に関して、Fangerらては赤・青色照明下 で被験者に好ましい温度を調整させる塞験を行い、赤色照明の場合、 青色照明に比べ 0.4 C ほど低い温度を好むという結果を得た。しかし 実験環境が極端な光色であるため、実際の環境では照明の光色が熱的
快適性に及ほす影響はないとしている。また大野ら8) は室温が寒·暑 不快条件から中立温度条件への過渡状態において、温冷感、快適感に 色彩による差違が示され、hue-he at仮説に合致する実験結果を得てい る。彼らの研究の上うに寒色・暖色系の色相の差違が人の温冷感や快 適感に影響を及ほすような結果を見いだした研究は少なく、諸環境条 件を定常状態として行った研究9)10)では色相による差違は人体心理 反応に複合的に影響を及涩さないとしている。hue-he at仮説に関する 研究では、寒色·暖色系の色相に統一した空間に拀いて研究を行って いるものがほとんどであるが、室内設計に適用する際、あまり一般的 な空間であるとは考えにくい。そこで寒色・暖色系の色相を光源の色 温度の高低として捉え、hue-he at 仮説を検証する研究は、より穾空間 に即していると考えられる。そこで、本研究は作用温度、照度レベル、 光源の種類を環境条件として組み合わせ、その組み合わせ条件が温熱 環境からもっとも影響を受けるとされている、人体生理反応としての 皮䖉温抢上び心理反応としての温冷感、快適感に及ぼす複合的影響の 検討を行った。

\section{2. 実験計画}

実験条件を表 1 に示す。実験室の環境条件は以下の通りである。作 用温度は暑くも寒くもない熱的中立温度条件として $28^{\circ} \mathrm{C}^{11)}$ を、寒冷、
* 名古屋工業大学大学院社会開発工学専攻 院生·修士 (工学)

** 名古屋工業大学大学院都市循環システム工学尃攻 教授・工博
Graduate Student, Dept. of Architecture, Nagoya Institute of Technology, M. Eng. Prof., Dept. of Environmental Technology and Urban Planning, Graduate School of Eng., Nagoya Institute of Technology, Dr. Eng. 
暑熱条件を $25^{\circ} \mathrm{C} 、 31^{\circ} \mathrm{C}$ と設定した。照度レベルはJ约による照度基準 （JIS Z 9110）から選定した。高照度条件として事務所、住宅等で細 かい視作業を行う場合の照度基準から $1000 \mathrm{~lx}$ を設定した。低照度条 件として事務所の執務室以外、また住宅の全般照明の照度基準加 $100 \mathrm{~lx}$ を設定した。そして、それらの中間的な照度条件として事務所 の執務室の照度基準から $500 \mathrm{x}$ を設定した。光源は使用頻度の高い白 色蛍光ランプ（色温度 $4200 \mathrm{~K}$ ) と白熱電球（同 $2850 \mathrm{~K}$ ）の 2 種類と した。相対湿度は $55 \%$ を目標に制御した。気流速度は $0.1 \mathrm{~m} / \mathrm{s}$ 以下と なるよう制御した。すべての被験者にたいして、それらを組み合わせ た計 18 条件を曝露した。前室の環境条件は、作用温度 $28^{\circ} \mathrm{C} 、$ 照度 $500 \mathrm{~lx}$ 、光源は白色蛍光ランプとした。相対湿度、気流速度は実験室 と同一条件とした。

実験は名古屋工業大学環境実験室内で行った。実験室、前室概略図 および照明器具配置図を図1に示す。環境実験室内にアルミ製のアン グルで寸法 $2800 \times 2400 \times 2000 \mathrm{~mm}$ のブースを2基作製し、それぞ れ実験室、前室とした。壁温、天井温、床温が気温と等しくなるよう に灰色（N5.5）のカーテンで周囲を覆った。温湿度制御は実験室、前 室ともパッケージ型エアコンで行った。実験室における作用温度の平 均と標準偏差は 3 条件でそれぞれ $25.4^{\circ} \mathrm{C}\left( \pm 0.3^{\circ} \mathrm{C}\right) 、 28.1^{\circ} \mathrm{C}( \pm 0.3$ $\left.{ }^{\circ} \mathrm{C}\right) 、 30.7^{\circ} \mathrm{C}\left( \pm 0.4^{\circ} \mathrm{C}\right)$ であった。実験室にお忖る相対湿度と気流速 度の平均と標準偏差はそれぞれ、 $55.9 \%( \pm 7.5 \%) 、 0.02 \mathrm{~m} / \mathrm{s}( \pm$ $0.01 \mathrm{~m} / \mathrm{s}$ ) であった。蛍光ランプの場合、照度レベルは蛍光ランプの 灯数で制御した。100 lx 条件は $10 \mathrm{~W}$ 蛍光ランブを 2 灯、500 lx 条件 は $40 \mathrm{~W}$ 蛍光ランプを 2 灯、 $1000 \mathrm{~lx}$ 条件は $40 \mathrm{~W}$ 蛍光ランプを 4 灯使 用した。白熱電球の場合、照度レベルは $60 \mathrm{~W}$ 白熱電球 14 灯をスライ ダックを用いて制御した。

実験は 1995 年 8 月 7 日から 1995 年 9 月 26 日の期間に行った。実 験は午前 1 回、午後 2 回の 1 日 3 回以内とし、1 日に同に゙被験者が連 続して実験を行わないように調整した。実験条件、実験開始時刻が規 則的にならないようランダムに実験を行った。

被験者は表 2 に示す健康な青年男子 4 名である。被験者には適当な 報酬が支払われた。今回は複合的影響の基本的性状を把握することを 目的としているため、着衣熱抵抗などの外的要因をなるべく少なくす るため、着衣条件はトランクスのみのほほ裸体とした。実験は1名ず つで行った。実験中、被験者に何かを凝視するような教示は行わず、 また読書は禁じた。

実験手順を図 2 に示す。最初に実験当日の食事の時間、体調などを 被験者に記入させ、一方で熱電対を被験者に装着した。熱電対装着 後、前室にて被験者を 30 分間椅座安静にさせた。安静後、実験室に て各実験条件に被験者を椅座安静状態で 60 分間曝露させた。

測定項目を表3に示す。乾湿球温はアスマン通風乾湿計と $0.3 \mathrm{~m} \mathrm{~m} \phi$ $\mathrm{T}$ 型熱電対を用いて 30 秒間隔で測定した。気流速度は熱式風速計を 用いて 1 分間隔で測定した。壁温、天井温、床温、照明器具表面温は $0.3 \mathrm{~m} \mathrm{~m} \phi \mathrm{T}$ 型熱電対を用いて 30 秒間隔で測定した。平均放射温度は Horikoshi ら ${ }^{12)}$ の直方体人体モデルを用いて各形態倸数を算出した。 照度はシリコンフォトセルデジタル照度計を用い、被験者が着席する 実験室抢よび前室中央の床上 $85 \mathrm{~cm}$ の水平面照度を測定した。

平均皮膚温注Hardy-Dubo is ${ }^{13)}$ の12点を重みづけして算出した。各 部位皮虙温は0.2 $\mathrm{mm}$ фT型熱電対をサージカルテープにて貼付し、30 秒間隔で計測した。舌下温は $0.2 \mathrm{~mm} \phi \mathrm{T}$ 型熱電対を用いて 30 秒間隔
表 1 実験条件

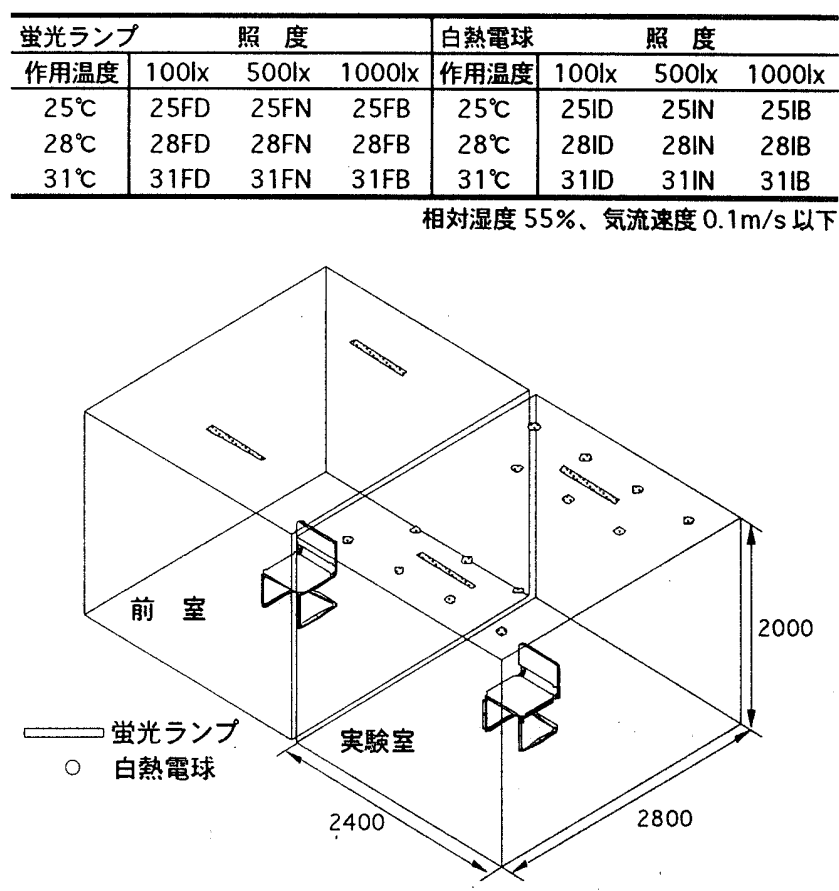

図 1、実験室、前室概略図および照明器具配置図

表 2 被験者デー夕

\begin{tabular}{|c|c|c|c|c|}
\hline $\begin{array}{c}\text { 被験者 } \\
\text { A } \\
\text { B } \\
\text { C } \\
\text { D } \\
\end{array}$ & $\begin{array}{c}\text { 身 } \mathrm{cm} \\
177.5 \\
176.7 \\
166.5 \\
167.5 \\
\end{array}$ & $\begin{array}{c}\text { 体重 } \mathrm{kg} \\
69.9 \\
55.5 \\
60.3 \\
55.4 \\
\end{array}$ & 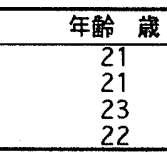 & 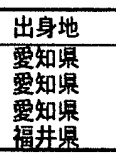 \\
\hline 实験開始 & 実䭾 & & & 实験終了 \\
\hline-30 分 & 前 室 & & 実験室 & 60分 \\
\hline
\end{tabular}

図 2 実験手順

表 3 測定項目

\begin{tabular}{|c|c|}
\hline 乾湿球温 & アスマン通風乾湿計・ $0.3 \mathrm{~mm} \phi \mathrm{T}$ 型熱霹対 $($ 床上 $70 \mathrm{~cm})$ \\
\hline 気流速度 & 熟式風速計（床上 $70 \mathrm{~cm} ）$ \\
\hline 表面温度 & $0.3 \mathrm{~mm} \phi$ T型熱電対 $($ 床上 $70 \mathrm{~cm}$ ) \\
\hline 水平面照度 & シリコンフォトセルテジタル照度計 (床上 $85 \mathrm{~cm})$ \\
\hline 皮成温 & $0.2 \mathrm{~mm} \phi T$ 型熱䨞対にてHardy-DuBoisの12点を測定 \\
\hline 舌下温 & $0.2 \mathrm{~mm} \phi$ T型熱電対 \\
\hline 心理反応 & 直線評定尺度（温冷感・快適感）图 3 参照 \\
\hline
\end{tabular}

$\underset{\text { 寨い }}{\longrightarrow} \underset{\text { 温合感 }}{\longrightarrow} \frac{\text { 不快 }}{\longrightarrow}$

图 3 直線評定尺度

で計測した。心理反応測定は図3に示す直線評定尺度 ${ }^{14)}$ を用い、5分 間隔で被験者に記入させた。被験者には直線評定尺度の温冷感、快適 感の両極は暑い、寒いおよび快適、不快の極限を示すことを教示し評 定させた。快適感は環境全体を評定させた。直線評定尺度は統計解析 を行う際、0から 100 の数值を割り当てた間隔尺度として取り扱っ た。

\section{3. 実験結果および考察}

3.1. 人体生理反応としての平均皮虚温に及ほすす複合的影響 3-1-1. 作用温度が平均皮䖉温に及は影響 
曝露終了時の作用温度に対する平均皮膚温の関倸を図 4 に示す。 デー夕は被験者 4 名の平均である。作用温度が高いほど、平均皮䖉温 は高くなった。作用温度と平均皮膚温には正の相関 $(\mathrm{r}=0.93 、 \mathrm{p}<$ 0.01 )が認められた。

\section{$3-1 \cdot 2$. 照度条件が平均皮虞温に及ほす影響}

作用温度ごとにみると、 $25^{\circ} \mathrm{C}$ 条件では各光源とも、500 lx、1000 lx 条件 (N、B) に比心゙、 $1001 \mathrm{x}$ 条件 (D) の平均皮虐温は $0.5^{\circ} \mathrm{C}$ 程度低 かった。500 lx、1000 lx 条件の平均皮膚温は各光源ともほほ等しく、 蛍光ランプは $32.7^{\circ} \mathrm{C}$ 程度、白熱電球は $33.2^{\circ} \mathrm{C}$ 程度であった。 $28^{\circ} \mathrm{C}$ 条 件では蛍光ランプの場合、500 lx、1000 lx 条件 $(28 \mathrm{FN} 、 28 \mathrm{FB})$ に比 心 、 $100 \mathrm{~lx}$ 条件 (28FD) の平均皮䖉温は $0.4^{\circ} \mathrm{C}$ 程度高く、白熱電球の 場合、5001x、1000 xx条件 $(28 \mathrm{IN} 、 28 \mathrm{~B})$ に比心゙、100 lx 条件 (28ID) の平均皮虚温は 0.4 C 程度低かった。 $500 \mathrm{~lx} 、 1000 \mathrm{~lx}$ 条件の平均皮虔 温岷各光源ともほぼ等しく、蛍光ランプは $33.7^{\circ} \mathrm{C}$ 程度、白熱電球は $34.1^{\circ} \mathrm{C}$ 程度であった。 $31^{\circ} \mathrm{C}$ 条件では、各光源とも平均皮膚温は 34.5 C付近であった。照度条件間で分散分析を行ったところ、すべての照 度条件間で平均皮膚温に有意差 $(\mathrm{p}<0.05)$ は認められなかった。杉 本 ${ }^{15)}$ は人体生理反応としての平均心拍数が、照度レベルの影響を受 けることを示したが、平均皮膚温には照度レベルの影響は認められな かった。

\section{3・1-3. 光源の種類が平均皮虐温に及ぼす影響}

作用温度ごとにみると、2 $5^{\circ} \mathrm{C}$ 条件では蛍光ランプに比心、白熱電球 の平均皮膚温は各照度条件とも高く、その差は最大で 0.5 Cであった。 $28^{\circ} \mathrm{C}$ 条件では蛍光ランプ $500 \mathrm{~lx} 、 1000 \mathrm{~lx}$ 条件 $(28 \mathrm{FN} 、 28 \mathrm{FB})$ に比 心゙、白熱電球 $500 \mathrm{~lx} 、 1000 \mathrm{~lx}$ 条件 $(28 \mathrm{IN} 、 28 \mathrm{IB})$ の平均皮膚温は0.3 ${ }^{\circ} \mathrm{C}$ 程度高く、蛍光ランプ $100 \mathrm{~lx}$ 条件 (28FD) に比べ、白熱電球 $100 \mathrm{~lx}$ 条件 (28ID) の平均皮膚温は 0.4 C 程度低かった。 $31^{\circ} \mathrm{C}$ 条件では、ど の条件も平均皮膚温はほ注等しかった。光源間で分散分析を行ったと ころ、すべての光源間で平均皮膚温に有意差 $(\mathrm{p}<0.05)$ は認められ なかった。

以上から人体生理反応としての平均皮庴温は作用温度の影響を受け るが、照度レベル、光源の種類による明確な影響は認められなかっ た。

\section{2. 人体心理反応としての温冷感に及ぼす複合的影響}

3-2-1，照度条件、光源の種類による温冷感の比較（作用温度 $25^{\circ} \mathrm{C}$ )

作用温度 $25^{\circ} \mathrm{C}$ 条件の温冷感の経時変動を照度条件、光源ごとに図 5 に、照度条件間抢よび光源間の分散分析の結果を表 4 に示す。図は 被験者 4 名の平均である。照度条件で比較すると、蛍光ランプの場合、 図5より曝露中、温冷感は照度条件が高いはど暑い方向の反応であっ た。表4より、5\%の有意水準では有意差は認められないが、10\%の 有意水準で分散分析を試みると、温冷感に有意差が認められ、図表よ り温冷感が照度レベルの影響を全く受けないとは考え難く、検討の余 地があると考えられる。白熱電球の場合、図 5 より曝露開始時、温冷 感は照度条件が高い活ど暑い方向の反応であり、曝露 15 分経過頃か ら各照度条件とも温冷感は、熱的中立上りやや寒い方向（数值にして 45 付近）に推移した。表 4 より曝露開始頃の温冷感に照度条件によ る有意差 $(p<0.05)$ が認められた。

光源の種類で比較すると、図 5 上り曝露中、各照度条件とも蛍光ラ ンプに比へ、白熱電球の温冷感は概权暑い方向の反忘であった。表 4 上り、 $100 \mathrm{~lx}$ 条件 (D) は曝露 15 分～ 20 分経過頃、 $500 \mathrm{~lx}$ 条件 $(\mathrm{N})$

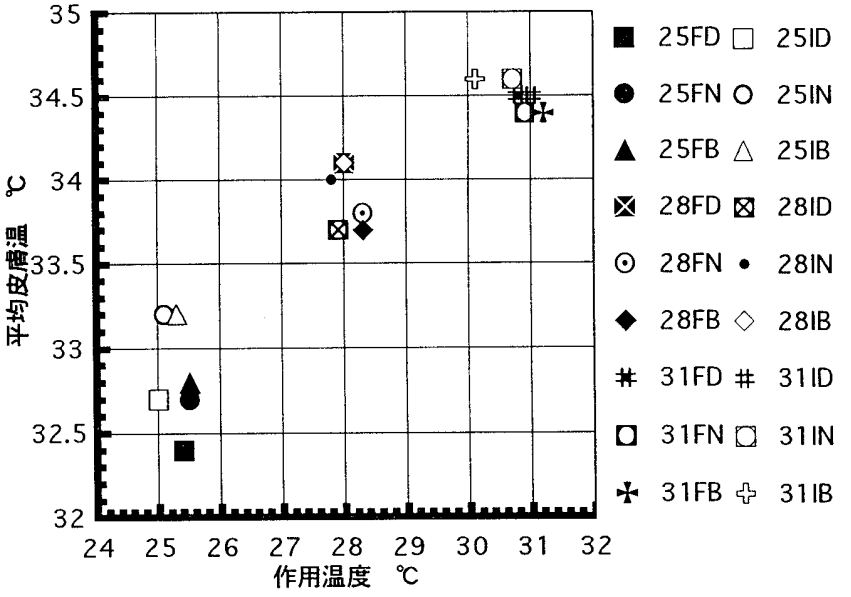

図 4 作用温度と平均皮膚温の関倸

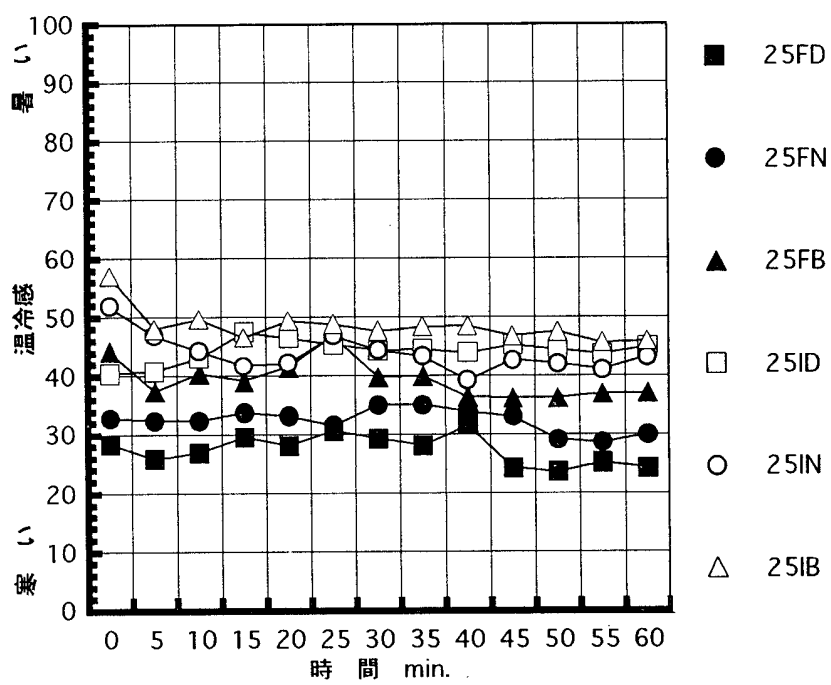

図 5 温冷感の経時変動（作用温度 $25^{\circ}$ C 条件）

表 4 温冷感の照度間および光源間の分散分析の結果 $\left(25^{\circ} \mathrm{C}\right.$ 条件 $)$

\begin{tabular}{|c|c|c|c|c|c|c|c|c|c|c|c|c|c|}
\hline 曝露時間 $\mathrm{min}$. & 0 & 5 & 10 & 15 & 20 & 25 & 30 & 35 & 40 & 45 & 50 & 55 & 60 \\
\hline 虽光ランプ & + & - & - & - & - & + & - & - & - & - & - & - & $t$ \\
\hline 白熱電球 & + & $*$ & $*$ & - & - & - & - & - & - & - & - & - & - \\
\hline $1001 x$ & - & + & + & * & $*$ & - & - & - & - & - & + & - & + \\
\hline $5001 x$ & $* *$ & $*$ & - & + & - & - & - & - & - & - & - & - & - \\
\hline $10001 x$ & + & - & - & - & - & - & + & + & + & $* *$ & $*$ & $*$ & $t$ \\
\hline
\end{tabular}

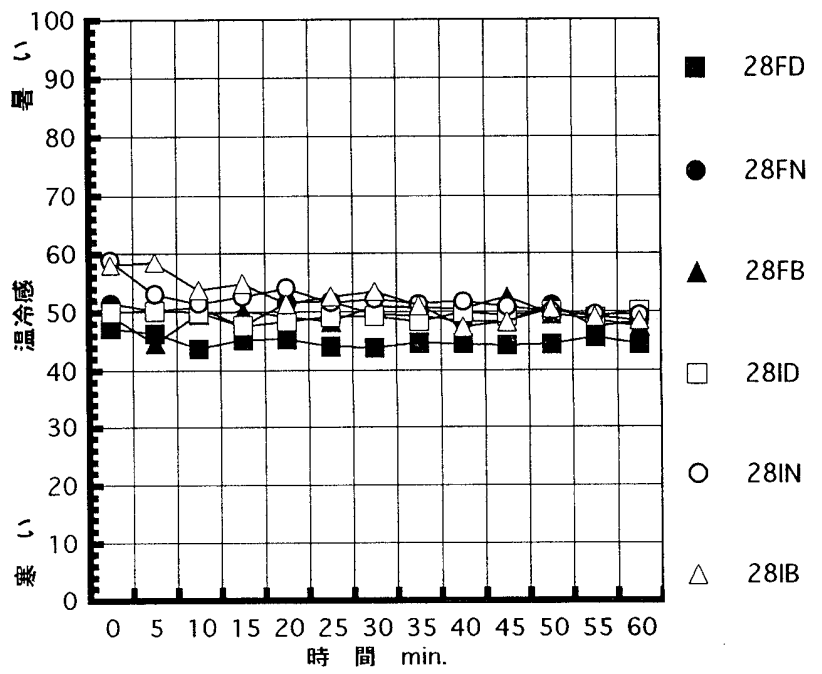

図 6 温冷感の経時変動（作用温度 $28^{\circ} \mathrm{C}$ 条件） 
は曝露開始時、 $1000 \mathrm{x}$ 条件 (B) は曝露終了頃の温冷感に光源の種類 による有意差 $(\mathrm{p}<0.05)$ が認められた。

3-2-2. 照度条件、光源の種類による温冷感の比較 (作用温度 $28^{\circ} \mathrm{C}$ )

作用温度 $28^{\circ} \mathrm{C}$ 条件の温冷感の経時変動を照度条件、光源ごとに図 6 に、照度条件間および光源間の分散分析の結果を表 5 に示す。図は 被験者 4 名の平均である。照度条件で比較すると、蛍光ランプの場合、 図 6 より $100 \mathrm{~lx}$ 条件 (28FD) は曝露中、温冷感は熱的中立上りやや 寒い方向（数值にして45 付近）の反応であった。5001x、1000 lx 条 件 $(28 \mathrm{FN} 、 28 \mathrm{FB})$ は曝露中、温冷感は熱的中立付近の反応であった。 表 5 上り照度条件による有意差は認められなかった。白熱電球の場 合、図6より $500 \mathrm{~lx} 、 1000 \mathrm{~lx}$ 条件 $(28 \mathrm{~N} 、 28 \mathrm{BB})$ は目露開始後、温 冷感は寒い方向に推移し、曝露 10 分経過頃から熱的中立付近で一定 となった。100 lx 条件 (28ID) は曝露中、温冷感は熱的中立付近の反 応であった。表 5 より曝露開始頃の温冷感に照度条件による有意差 $(\mathrm{p}$ く0.05) が認められた。

光源の種類で比較すると、図 6 上り曝露 15 分経過頃までは蛍光 ンプに比べ、白熱電球の温冷感は各照度条件とも概ね暑い方向の反応 であり、それ以降は蛍光ランプ $100 \mathrm{~lx}$ 条件（28FD）を除き、各光源 とも温冷感は、熱的中立付近の反応であった。表5より100 kx条件 (D) は曝露開始頃、 $1000 \mathrm{~lx}$ 条件 (B) は曝露開始時抢上び曝露 40 分経過 後の温冷感に光源の種類による有意差 $(\mathrm{p}<0.05)$ が認められた。 $5001 \mathrm{x}$ 条件 $(\mathrm{N})$ は温冷感に有意差は認められなかった。

作用温度 $31^{\circ} \mathrm{C}$ 条件では、温冷感に照度条件、光源の種類による有 意差は何ら認められなかった。以上から照度条件、光源の種類が温冷 感に及ぼす複合的影響を概括すると、照度条件が温冷感に及ぼす影響 は、作用温度が $25^{\circ}$ Cあるいは $28^{\circ} \mathrm{C}$ で光源が白熱電球の場合、曝露 開始時の過渡状態において有意に認められた。作用温度が熱的中立温 度以下の場合、光源が蛍光ランプから白熱電球に変化する過渡状態に おいて、被験者は白熱電球を心理的に放射熱源として捉え、照度レ心゙ ルが高いほど光源の放射温度が高いと知覚し、その結果照度レバルが 高いほどより暑く感じたと考えられる。その後人体が温度馿化した定 常状態では、照度レベルは温冷感に影響を及はさないと考えられる。

光源の種類が温冷感に及ほす影響は、作用温度が $25^{\circ} \mathrm{C}$ あいは28 Cで有意に認められた。蛍光ランプに比べ白熱電球の温冷感が暑い方 向であったのは、光色が白色に見える蛍光ランプに比べ、赤みがかっ た白に見える白熱電球の環境を被験者がより暑く感じたと考えられ る。これは光源の光色を色相と捉えるならば、hue he at仮説とほぼ一 致する結果であると考方られる。作用温度 $28{ }^{\circ} \mathrm{C}$ 場合、曝露開始頃 にこの傾向が認められるが、作用温度 $25^{\circ} \mathrm{C}$ の場合、光源の種類が温 冷感に及ばす影響には照度条件によりタイムラグがあり、検討の余地 があると考えられる。

\section{3-3. 人体心理反応としての快適感に及ほすす複合的影響}

3-3-1. 照度条件、光源の種類による快適感の比較（作用温度 $25^{\circ} \mathrm{C}$ ) 作用温度 $25^{\circ} \mathrm{C}$ 条件の快適感の経時変動を照度条件、光源ごとに図 7 に、照度条件間抢上び光源間の分散分析の結果を表 6 に示す。図は 被験者 4 名の平均である。照度条件で比較すると蛍光ランプの場合、 図7より曝露中、照度条件が高いほど快適感は快適方向の反応であっ た。表 6 上り曝露 35 分、40 分経過後抢上び曝露終了時の快適感に照 度条件による有意差 $(\mathrm{p}<0.05)$ が認められた。白熱電球の場合、図 7 上り曝露時間が経過するにつれ、各照度条件とも快適感は 70 付近
表 5 . 温冷感の照度間抢よび光源間の分散分析の結果 $\left(28^{\circ} \mathrm{C}\right.$ 条件)

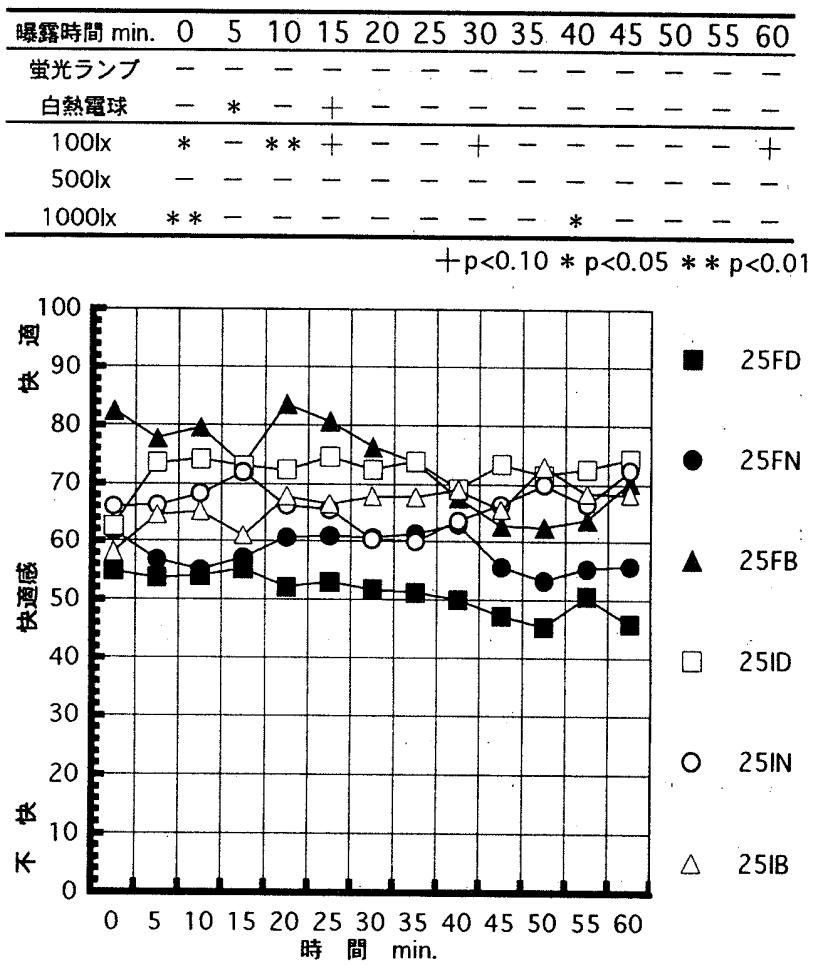

図 7 快適感の経時変動（作用温度 $25^{\circ} \mathrm{C}$ 条件）

表 6 快適感の照度間および光源間の分散分析の結果 $\left(25^{\circ}\right.$ C条件)

\begin{tabular}{|c|c|c|c|c|c|c|c|c|c|c|c|c|c|}
\hline 曝露時間 $\mathrm{min}$. & 0 & 5 & 10 & 15 & 20 & 25 & 30 & 35 & 40 & 45 & 50 & 55 & $\overline{60}$ \\
\hline 蛍光ランブ & - & - & - & - & - & - & - & * & * & - & - & - & * \\
\hline 白熱雷球 & - & - & - & - & - & - & - & - & - & - & - & - & - \\
\hline $1001 x$ & - & - & - & - & - & - & - & - & - & - & - & - & - \\
\hline $5001 x$ & - & - & - & - & - & - & - & - & - & - & - & - & - \\
\hline $10001 x$ & $*$ & - & - & - & - & - & - & - & - & - & - & - & - \\
\hline
\end{tabular}

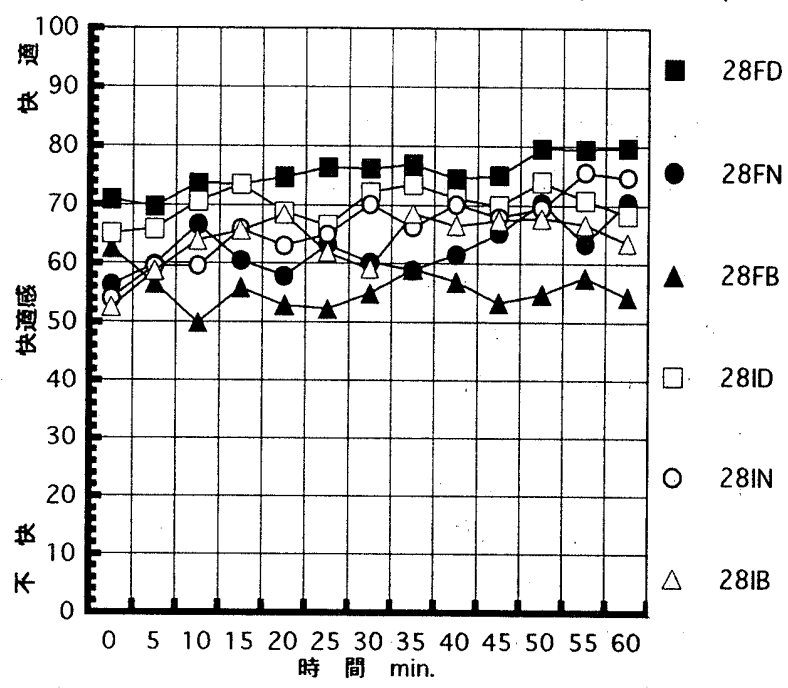

図8 快適感の経時変動（作用温度 $28^{\circ}$ C 条件)

表 7 快適感の照度間および光源間の分散分析の結果 $(28 \mathrm{C}$ 条件

\begin{tabular}{|c|c|c|c|c|c|c|c|c|c|c|c|c|c|}
\hline 曝露時間 min. & 0 & 5 & 10 & 15 & 20 & 25 & 30 & 35 & 40. & 45 & 50 & 55 & 60 \\
\hline 虽光ランプ & - & - & $* *$ & - & + & * & - & - & - & - & * & - & + \\
\hline 白熱雷球 & - & - & - & - & - & - & - & - & - & - & - & - & * \\
\hline $1001 x$ & - & - & - & - & - & - & - & - & - & - & - & - & - \\
\hline $5001 x$ & - & - & - & - & - & - & - & - & - & - & - & - & - \\
\hline $10001 x$ & - & - & - & + & $*$. & - & - & + & - & $*$ & + & - & * \\
\hline
\end{tabular}


に推移した。表 6 より快適感に照度条件による有意差は認められな かった。

光源の種類で比較すると、図 7 より $100 \mathrm{~lx} 、 500 \mathrm{~lx}$ 条件 (D、N)の 場合、曝露中蛍光ランプに比べ、白熱電球の快適感は概秋快適方向の 反応であった。1000 x 条件（B）の場合、曝露 35 分経過までは白熱 電球に比べ、蛍光ランプの快適感は快適方向の反応であったが、それ 以降はほほ等しい反応であった。表6より、10001x条件 (B) の曝露 開始時の快適感に光源の種類による有意差 $(\mathrm{p}<0.05)$ が認められた。 $3-3-2$. 照度条件、光源の種類による快適感の比較 (作用温度 $28^{\circ} \mathrm{C}$ )

作用温度 $28^{\circ} \mathrm{C}$ 条件の快適感の経時変動を照度条件、光源ごとに図 8 に、照度条件間扔よび光源間の分散分析の結果を表 7 に示す。図は 被験者 4 名の平均である。照度条件で比較すると、蛍光ランプの場合、 図8より曝露中、照度条件が低いほど快適感は快適方向の反応であっ た。表7 から曝露 10 分、25 分および50 分経過後の快適感に照度条 件に上る有意差 $(\mathrm{p}<0.05)$ が認められた。白熱電球の場合、 $500 \mathrm{~lx}$ 条件 $(28 \mathrm{~N})$ ) の快適感は曝露中快適方向に推移し、曝露終了時には白 熱電球の照度条件のなかで、最も快適の反応となった。表7より曝露 終了時の快適感に照度条件による有意差 $(\mathrm{p}<0.05)$ が認められた。

光源の種類で比較すると、図 8 より $500 \mathrm{k} 、 1000 \mathrm{~lx}$ 条件 $(\mathrm{N} 、 \mathrm{~B})$ の 場合、曝露中蛍光ランプに比心゙、白熱電球の快適感は概ね、快適方向 の反応であった。100 lx 条件 (D) の場合、曝露中、白熱電球に比べ、 蛍光ランプの快適感は概ね、快適方向の反応であった。表 7 より $1000 \mathrm{~lx}$ 条件 (B) の曝露 20 分、45 分経過後抢よび曝露終了時の快適 感に光源の種類による有意差 $(\mathrm{p}<0.05)$ が認められた。

作用温度 $31^{\circ} \mathrm{C}$ 条件では、快適感に照度条件、光源の種類による有 意差は何ら認められなかった。以上から、照度条件、光源の種類が快 適感に及仿す複合的影響を概括すると、照度条件が快適感に及ぼす影

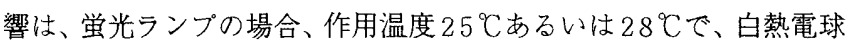
の場合、作用温度 $28^{\circ} \mathrm{C}$ の曝露終了時に有意に認められた。蛍光ラン プ $25^{\circ} \mathrm{C}$ の場合、照度レベルが高いほど快適感が快適方向に、蛍光う ンプ 28 Cの場合、照度レベルが低いほど快適感が快適方向となる傾 向が示された。白熱電球 $28^{\circ} \mathrm{C}$ の場合、500 $\mathrm{lx}$ が最も快適となる傾向が 示された。本研究で用いた快適感は、環境全体を評定して扔り、照明 のみを評定している既往の研究結果と単純に比較することはできない と考えられる。堀江ら ${ }^{16)}$ は、不快さは巽種環境要因を加算的に表現 することができる非特異的尺度であることを示したが、本研究で用い た快適感も異種環境要因を加算的に表現することができるならば、快 適感の差を光源の照度レベルあるいは種類に起因するものとして抽出 できると考えられる。以下、快適感をそのように考え既往の研究など

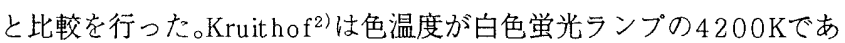

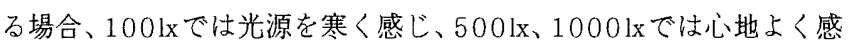
じると報告している。蛍光ランプ $25^{\circ} \mathrm{C}$ 結果はKruithof とほ汪同様 の傾向を示し、蛍光ランプ $28^{\circ} \mathrm{C}$ の結果は異なる傾向を示した。また 色温度が白熱電球の $2850 \mathrm{~K}$ である場合、5001x、1000 1xでは光源を 不快に感じると報告しており、白熱電球 $28^{\circ} \mathrm{C}$ 結果仕異なる傾向を 示した。CEガイド4)によると適当な照度レベルは、白色蛍光ランプ では $1000 \mathrm{~lx} \sim 2000 \mathrm{~lx}$ 、白熱電球では500 $\mathrm{x}$ 以下としており、蛍光ラ ンプ $25^{\circ} \mathrm{C}$ 、白熱電球 $28^{\circ} \mathrm{C}$ は一致する結果となり、蛍光ランプ $28^{\circ} \mathrm{C}$ は 異なる結果となった。しかし蛍光ランプの場合、照度条件が快適感に 及活す影響は作用温度条件によりタイムラグがあり、検討の余地があ

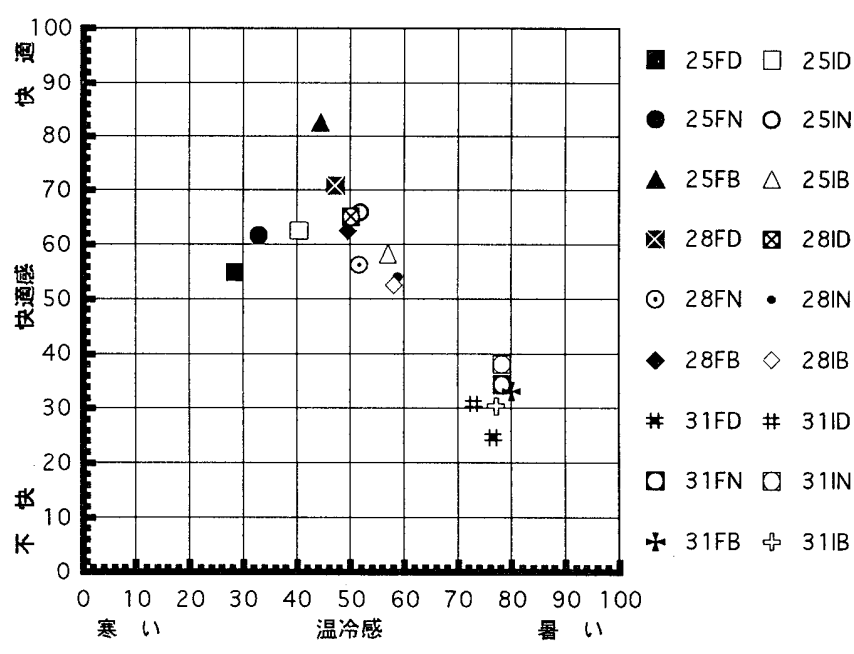

図 9 温冷感と快適感の関係（曝露開始時）

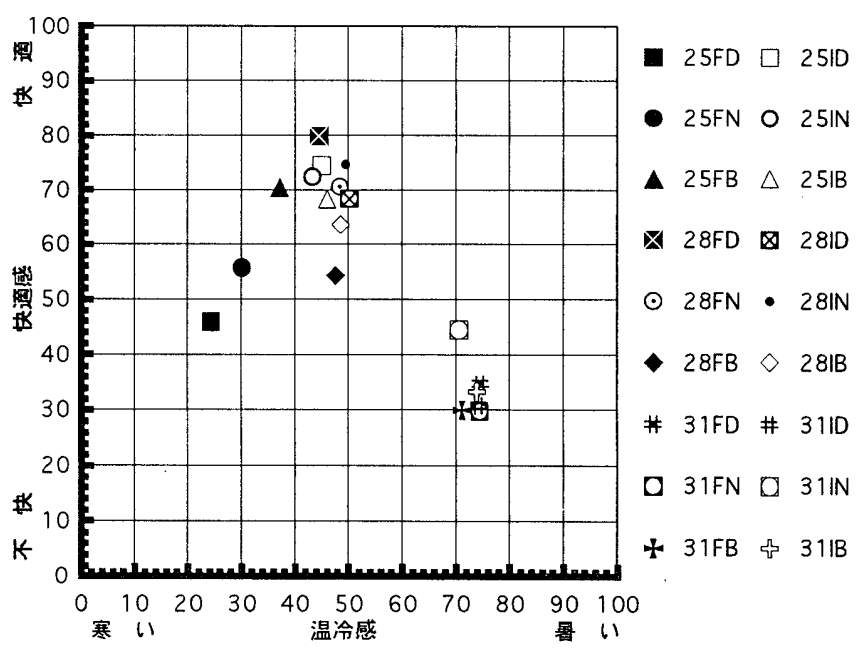

図 10 温冷感と快適感の関係（曝露終了時）

ると考えられる。

光源の種類が快適感に及ぼす影響は、作用温度 $25^{\circ} \mathrm{C}$ あいは 28 ${ }^{\circ} \mathrm{C} 、$ 照度 $1000 \mathrm{~lx}$ の場合に有意に認められた。2 $5^{\circ} \mathrm{C} 1000 \mathrm{~lx}$ の場合、懪 露開始時の過渡状態で白熱電球に比ベ、蛍光ランプの快適感が快適方 向となる傾向が示された。2 $8^{\circ} \mathrm{C} 1000 \mathrm{~lx}$ の場合、蛍光ランプに比べ、 白熱電球の快適感は快適方向となる傾向が示された。2 $5^{\circ} \mathrm{C} 1000 \mathrm{~lx}$ の 結果はKruithof とほほ同様の傾向を示し、28 ${ }^{\circ} \mathrm{C} 1000 \mathrm{~lx}$ の結果は異な る傾向を示した。

$3 \cdot 4$. 温冷感と快適感の関倸

暴露開始時の温冷感にたいする快適感の関係を図9に示す。図は被 験者 4 名の平均である。最も快適であったのは、蛍光ランプ $25^{\circ} \mathrm{C}$ $1000 \mathrm{~lx}$ 条件 (25 FB) であった。その時の温冷感は熱的中立より若干 寒い方向（数值にして 42 程度）であった。

曝露終了時の温冷感にたいする快適感の関倸を図 10 に示す。図は 被験者 4 名の平均である。最も快適であったのは、蛍光ランプ $28^{\circ} \mathrm{C}$ $100 \mathrm{~lx}$ 条件 (28FD) であった。その時の温冷感は熱的中立上り若干 寒い方向 (数值にして 45 程度) であった。作用温度 $25^{\circ} \mathrm{C} 、$ 光源が白 熱電球の各照度条件は、温冷感と快適感の関倸が作用温度 $28^{\circ} \mathrm{C}$ 条件 の蛍光ランプ $500 \mathrm{~lx}$ 条件 $(28 \mathrm{FN}) 、$ 白熱電球 $100 \mathrm{~lx}$ 条件 $(28 \mathrm{D}) 、 500 \mathrm{~lx}$ 条件 $(28 \mathrm{~N})$ とほほ等しかった。これらの条件は物理環境によらず心 理反応が等しいと考えられるが、それら作用温度 $25^{\circ}$ C条件と作用温 度 $28^{\circ} \mathrm{C}$ 条件では平均皮膚温の差が最大で $2.4^{\circ} \mathrm{C}$ あったこれは作用温 
度が熱的中立温度以下で、光源が白熱電球である場合、心理反応に現 れない生理的熱ストレスを人体が受けている可能性があることが示唆 される。

温泠感ど快適感の関係を概括すると、曝露開始時、曝露終了時とも に快適感が最も快適となるのは、温冷感が熱的中立上り若干寒い方向 であった。これは夏季至適域を提案した志村ら 17)の研究と同様の結 果となった。曝露開始時の過渡状態と曝露終了時の定常状態では最も 快適であった作用温度、照度レベルは異なったが、光源は両状態とも 蛍光ランプであった。最も快適となる場合の光源が蛍光ランプである のはObara ${ }^{18)}$ が指摘しているように、日本人と蛍光ランプには特異な 関係があることも考えられる。

\section{4. まとめ}

本研究は、作用温度 3 条件 $\left(25^{\circ} \mathrm{C} 、 28^{\circ} \mathrm{C} 、 31^{\circ} \mathrm{C}\right)$ 、照度 3 条件 $(100 \mathrm{~lx}$ 、 $500 \mathrm{~lx} 、 1000 \mathrm{~lx}$ )、光源 2 種類（白色蛍光ランプ、白熱電球）を実験 条件として、異なる作用温度、照度レベル、光源の組み合わせが人体 の生理・心理反応に及ほす複合的影響を青年男子 4 名を用いた実験を とおして検討した。その結果以下の結論を得た。

1. 人体生理反応としての平均皮䖉温は作用温度の影響を受けるが、 照度レベル、光源の種類による明確な影響は認められなかった。

2. 人体心理反応としての温冷感を照度レベルで比較すると、作用温 度 $25^{\circ} \mathrm{C}$ あるいは $28^{\circ} \mathrm{C} て ゙$ 光源が白熱電球の場合、光源が变化する過渡 状態において、照度レベルが高いほど、温冷感は暑い方向となる傾向 が示されだ。

3. 温冷感を光源の種類で比較すると、作用温度 $25^{\circ} \mathrm{C}$ あいは $28^{\circ} \mathrm{C}$ の場合、蛍光ランプに比ベ、白熱電球の温冷感は暑い方向となる傾向 が示された。光源の光色を色相と捉えるならば、hue-he at仮説とほほ 一致する結果となった。

4. 人体心理反応としての快適感を照度レベルで比較すると、作用温 度 25 Cで光源が蛍光ランプの場合、照度レベルが高いほど快適感が 快適方向となり、作用温度 $28^{\circ} \mathrm{C} て ゙$ 光源が蛍光ランプの場合、照度レ ベルが低いほど快適感が快適方向となる傾向が示された。作用温度 $28^{\circ}$ Cで光源が白熱電球の場合、500 x た。これらは、必ずしもKruithofの研究やCEガイドと一致する結果 とはならなかった。

5. 快適感を光源の種類で比較すると、 $25^{\circ} \mathrm{C} 1000 \mathrm{kx}$ の場合、曝露開 始時の過渡状態で白熱電球に比べ、蛍光ランプの快適感が快適方向と なる傾向が示された。2 $8^{\circ} \mathrm{C} 1000 \mathrm{~lx}$ の場合、蛍光ランプに比べ、白熱 電球の快適感は快適方向となる傾向が示された。2 $5^{\circ} \mathrm{C} 1000 \mathrm{~lx}$ の場合 はKruithof の研究とほほ同様の傾向を示し、28 ${ }^{\circ} 1000 \mathrm{k}$ の場合は異 なる傾向を示した。

本研究では被験者が 4 名であり、得られた結論をさらに一般的なも のとするには被験者数を増やした実験が必要であると考えられる。光 源の色温度と照度の関係がKruithofの研究やCEガイドと必ずしも一 致しなかったことが、日本人の特質によるものか、あるいは今回の実 験手順や条件によるものなのかは検討の余地があると考えられる。作 用温度 $31^{\circ} \mathrm{C}$ 条件では照度レベル、光源の種類が生理・心理反応に明 らかな影響を及ぼさなかったが、実験期間が夏季であったため、この ような結果になったことも考えられ、冬季に再度実験を行う必要性が あると考えられる。

\section{謝辞}

本研究を行うにあたり、その一部を卒業論文として実験及びデータ 整理にご協力いただいた名古屋工業大学学生 (当時) 伊藤芳男氏およ び、実験にご協力していただいた被験者各位に感謝の意を表します。

\section{引用文献}

1）日本建築学会編：設計計画バンフレット 30 冝光照明の計画, 彰国社, 1985 2) Kruithof, A. A. : TubularLum inescence Lam ps forGene rallllum ination, Philips Technical Review, Vol 6, No. 3, pp. 65 73,1941

3）中野美香，垣鐉直，堀越哲美，稲垣卓造：色温度と空温の複合条件評価に関 する実験的研究，日本建築学会大会学術講演梗既集，pp. 765 766, 1997

4)CE Public a tion No. 29, Guide on Inte rior Lighting, 1975

5）乾正雄：建築設計講座 照明と視環境，理工図查, 1978

6) Bennett, C. A. and Rey, P. : What's So Hot About Red? , Hum an Factors, Vol 14, No. 2, pp. 149 154,1972

7) Fanger, P:O., Bre um, N. O. and Je rking, E. : Can Colour and Noise Influence Man's The rmalCom fort?, Ergonom ics, Vol 20, No. 1, pp. 11 18, 1977

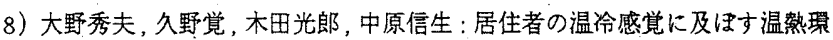
境と色彩環境の複合勃果に関する研究，日本建築学会計画系論文報告集，第374 号, pp. 8 18, 1987

9) Be rry, P. C.: Effect of Co bre d lltum ination upon Pe reeived Tem pe rature,J our nalof App lied Psychology, Vol 45, No. 4, pp. 248 250, 1961

10)Greene, T. C. and Bell, P. A. : AdditionalConside rations Conce ming the Ef fect of 'Warm' and 'Cool' WallCo burs on Ene rgy Conse rvation, Ergonom ics, VoL 23, No. 10, pp. 949 954,1980

11）堀越哲美，南野修，磯田憲生，小林陽太郎：人工気候室内にお打万温熱条 件々人体側条件の人体影響に関する実験的研究，日本建築学会論文報告集，第 229号, pp. 129 139, 1975

12) Ho rikoshi, T. and Ko bayashi, Y.: Configuration Factors be twe en a RectangularSo lid as a Mode lof the Hum an Body and RectangularPlanes, for Evaluation of the Influence of The rmalRadiation on the Hum an Body II. Characte ristics of Configuration Factors for the RectangularSolids, 日本建築学会計画系論文報告 集第267号pp. 91 101, 1978

13) Hardy, J. D. and DuBo is, E. F. : The Technic of Me asuring Radiation and Convection, Joumalof Nutrition, VoL 1 5, No. 5, pp. 461 475, 1938

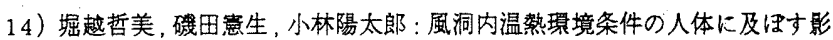
響に関する実験的研究（男子裸体）その 2 夏期平均皮唐温と温冷感申告, 空気 調和·衛生工学会学術講演会講演諭文集, pp. $27 \sim 30,1974$

15）杉本賢: 照明環境要㭟の生体への影響に関する研究-照度と生理負担の関 係 (その2) ，照明学会誌，第 65 巻, 第 4 号, pp. $41 \sim 45,1981$

16）堀江悟郎，桜井美政，松原斎樹，野口太郎: 室内における異種環境要因が もたらす不快さの加算的表現，日本建築学会計画系論文報告集，第387号, pp. $1 \sim 7,1988$

17）志村欣一, 屈越哲美，山岸明浩: 日本人を対象とした室内温湿度条件の至 適域に関する実験的研究, 日本建築学会計画系論文集, 第 480 号, pp. 15 24, 1996

18) Obara, K. : Fhorescent Home Lighting in J apan, Inte mational Lighting Re view, No. 2, pp. 38 41,1980

\section{本論文に関する既発表論文}

1）伊藤芳男，石井仁，宮本征一，堀越哲美：気温と照度が人体生理心理庈応に 及情す複合的影響〜光源を白熱電球とした場合〜，日本建筑学会東海支部研究 報告集, pp. $525 \sim 528,1996$

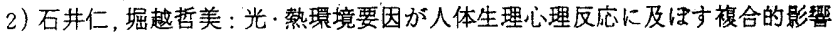
日本建筑学会大会学術講演梗概集, pp. 849 850,1996

3）石井仁，堀越哲美，尹仁：光・㠇環境要因が人体生理心理反応に及浔す複合 的影響その 2 曝露開始時における心理反応の検討, 日本建築学会大会学術講演 梗概集, pp. 763 764, 1997

（1998年 5 月 10 日原稿受理，1998年 9 月29日探用決定） 